\title{
The Role of Board Independence and Ownership Structure in Improving the Efficacy of Corporate Financial Distress Prediction Model: Evidence from India
}

\author{
Shilpa H. Shetty *(1) and Theresa Nithila Vincent \\ Department of Commerce, CHRIST (Deemed to Be University), Bengaluru 560029, India; \\ Nithila.vincent@christuniversity.in \\ * Correspondence: Shilpa.shetty@res.christuniversity.in
}

check for updates

Citation: Shetty, Shilpa H., and Theresa Nithila Vincent. 2021. The Role of Board Independence and Ownership Structure in Improving the Efficacy of Corporate Financial Distress Prediction Model: Evidence from India. Journal of Risk and Financial Management 14: 333. https://doi.org/10.3390/jrfm14070333

Academic Editor: Aviral

Kumar Tiwari

Received: 27 April 2021

Accepted: 25 June 2021

Published: 19 July 2021

Publisher's Note: MDPI stays neutral with regard to jurisdictional claims in published maps and institutional affiliations.

Copyright: (c) 2021 by the authors. Licensee MDPI, Basel, Switzerland. This article is an open access article distributed under the terms and conditions of the Creative Commons Attribution (CC BY) license (https:/ / creativecommons.org/licenses/by/ $4.0 /)$.
Abstract: The study aimed to investigate the role of non-financial measures in predicting corporate financial distress in the Indian industrial sector. The proportion of independent directors on the board and the proportion of the promoters' share in the ownership structure of the business were the non-financial measures that were analysed, along with ten financial measures. For this, sample data consisted of 82 companies that had filed for bankruptcy under the Insolvency and Bankruptcy Code (IBC). An equal number of matching financially sound companies also constituted the sample. Therefore, the total sample size was 164 companies. Data for five years immediately preceding the bankruptcy filing was collected for the sample companies. The data of 120 companies evenly drawn from the two groups of companies were used for developing the model and the remaining data were used for validating the developed model. Two binary logistic regression models were developed, M1 and M2, where M1 was formulated with both financial and non-financial variables, and M2 only had financial variables as predictors. The diagnostic ability of the model was tested with the aid of the receiver operating curve (ROC), area under the curve (AUC), sensitivity, specificity and annual accuracy. The results of the study show that inclusion of the two non-financial variables improved the efficacy of the financial distress prediction model. This study made a unique attempt to provide empirical evidence on the role played by non-financial variables in improving the efficiency of corporate distress prediction models.

Keywords: bankruptcy; board independence; financial distress; IBC; logistic regression; ownership structure

\section{Introduction}

In a country, healthy and sick businesses coexist. When businesses fail to maintain competitive efficiency, they get sick (Datta 2013). Sick businesses adversely affect the different stakeholder groups and the national economy at large. Consider the example of Enron, once the world's largest energy company that ranked seventh in the fortune magazine in early 2001 but filed for bankruptcy in December 2001. Not only Enron's employees lost jobs, but its audit firm Arthur Anderson also laid off thousands of its employees. The sharp and sudden decline in the stock price of Enron adversely affected the savings of ordinary investors, both direct and index-fund investors (Sridharan et al. 2002). Many other companies and financial institutions suffered losses because of the operational and financial credit extended to the company. The demise of Enron proved costly to other energy companies, as many projects in the industry were put on hold, and the industry had to bear the higher cost of financing due to an increase in the perceived risk and uncertainty in the business (Fox 2004). On 2 December 2001, Enron filed for bankruptcy protection from its creditors under Chapter 11 of the United States Bankruptcy Code (Forbes 2001).

In India, the Insolvency and Bankruptcy Code (IBC) 2016, is the law that governs insolvency and bankruptcy. It was introduced in 2016. Since its inception, the number of 
bankruptcy filings under IBC has been rising. According to an article in Business Today, manufacturing and construction are the worst hit, constituting over 50 percent of the total bankruptcy filings under the IBC (John 2019). Both manufacturing and construction belong to the industrial sector. The IBC follows the creditor-in-control model (Sahoo and Guru 2020) In creditor-oriented bankruptcy law, liquidation is largely the outcome of insolvency and bankruptcy procedure (Ayotte and Skeel 2013). A series of liquidations can result in a major economic crisis. The early detection of corporate financial distress can reduce the likelihood of a bankruptcy filing and eventually prevent the business from liquidation and save the economy. Therefore, a model that predicts potential business failure as early as possible would serve to reduce such losses by providing ample warning to the interested parties (Deakin 1972).

In the past, numerous researchers have proposed many models that predict the financial status of businesses. All models developed are an extension to the seminal works of Beaver, Altman and Ohlson (Manzaneque et al. 2016). Financial ratios formed the basis for the models developed by Beaver (1966), Altman (1968) and Ohlson (1980). In recent years, researchers argued that in addition to financial ratios, the use of non-financial ratios improves the predictive efficacy of the model. The present study is undertaken with the objective to investigate the role of non-financial measures in predicting corporate financial distress. Two non-financial variables were considered with the hypothesis that non-financial variables, such as board independence and proportion of the promoters share in the ownership structure of the business, improve the efficacy of the corporate financial distress prediction model. To examine this, two bankruptcy prediction models, M1 and M2, were developed using 5 years' data from 120 companies comprising an equal number of defaulting and non-defaulting companies. M1 was formulated with both financial and non-financial variables as predictors, while M2 consisted of only financial variables as predictors. Consequently, the comparison of the performances of the two models allowed us to determine the significance of non-financial measures in the corporate distress prediction model. The developed models were validated using a testing sample of 44 companies. The model resulting from the comparison is recommended for corporate financial distress prediction in the Indian industrial sector.

The remainder of the paper is organised as follows: In the next section, related literature is reviewed and a hypothesis is drawn. The review of the literature is followed by the research methodology, where the process of sample selection, details of variables, information on data collection and statistical tools employed for analysis are elaborated. Subsequently, the results of the analysis are discussed and, finally, conclusions are drawn in the last section.

\section{Review of Literature}

The review of the literature highlights the variables that were used as predictors for formulating corporate financial distress prediction models in the past. The literature is divided into two parts: review of financial measures that were used to predict financial distress and the non-financial measures that were used by researchers in the past in an attempt to improve the classification accuracy of the model.

\subsection{Corporate Financial Distress and Financial Measures}

In credit default prediction models, the variables include dependent and independent variables, also known as response and predictor variables. The dependent variable is usually a dichotomous variable and can have the value 0 or 1, i.e., defaulting or nondefaulting, respectively. However, Jones and Hensher (2004) mention mutually exclusive categories with values of 0,1 and 2, where 0 indicates firms that are going concerns and show no evidence of financial distress, 1 indicates firms that are going concerns but have experienced financial difficulties and 2 indicates firms that are no longer going concerns. Financial ratios constitute the primary independent or predictor variables. However, the number of ratios used by researchers in developing a model differed. Kim and Gu (2020) 
used one ratio to develop a model, while Xu et al. (2015) used twenty-three ratios. One should note, a higher number of factors does not guarantee a higher predictive ability (Gissel et al. 2007).

Liquidity, profitability, leverage, efficiency, and cash flow ratios were some of the commonly used financial ratios in the literature. Liquidity ratios comprising the current ratio and quick ratio are some of the most widely used financial ratios in financial distress prediction models. Pervan et al. (2011) used the CR ratio to predict company bankruptcy in Croatia. Waqas and Md-Rus (2018) identified the QR as a significant predictor of financial distress for Pakistani firms. Both the liquidity ratios have shown a negative association with the probability of occurrence of financial distress. The return on assets (ROA) and operating profit ratio (OPR) are the two profitability ratios considered in many studies. ROA was used by Singh and Mishra (2016) to develop a bankruptcy prediction model and Bandyopadhyay (2006) used OPR in developing a credit default prediction model in India. Both profitability ratios were shown to have a significant negative association with the event of financial distress in the respective studies. Leverage also played an essential role in predicting financial distress in the past. The debt to total assets ratio (DTAR) and interest coverage ratio (ICR) were mostly used as measures of leverage. Shetty et al. (2012) suggested a positive association of DTAR with bankruptcy in IT/ITES companies in India. While determining industrial sickness in India, Datta (2013) considered the ICR and found it to be inversely associated with industrial sickness. The total asset turnover ratio (TATR) and sales to working capital ratio (SWCR) are the two commonly found measures of efficiency. Rashid and Abbas (2011) recognised the TATR to be negatively significant in predicting bankruptcy in Pakistan. Obradovic et al. (2018) found the SWCR to be positive and significantly associated with corporate financial distress in Turkey. In recent years, researchers have also identified the significant role played by cashflows in predicting financial distress. The cash flow to sales ratio (CSR) and cash flow to total assets ratio (CTAR) successfully showed the efficiency of cashflows in predicting financial distress amongst companies. Obradovic et al. (2018) and Waqas and Md-Rus (2018) observed the CSR and CTAR, respectively, to be negatively associated with the event of bankruptcy.

\subsection{Corporate Financial Distress and Non-Financial Measures}

The relationship between non-financial measures and corporate financial distress has been a matter of interest to researchers since 1990. Before this, many researchers analysed the impact of non-financial variables, especially corporate governance measures on business performance. However, the review here focuses on the role of non-financial measures behind the events of financial distress and bankruptcy.

A series of studies were undertaken by Dairy and Dalton that investigated the association between corporate governance measures and the event of bankruptcy in a company. The studies comprised both financial and non-financial measures and had an equal number of defaulting and non-defaulting companies as samples. The financial measures represented profitability, liquidity and leverage. However, these financial measures were controlled while studying the relationship between governance measures and bankruptcy. The governance measures consisted of board composition and board leadership indicators. To summarise the results in Daily and Dalton (1994, 1995), corporate governance measures improved predictions in five and three years prior to bankruptcy. CEO turnover and board turnover are higher in the five years prior to bankruptcy. However, in the actual year of the bankruptcy filing, considering only financial ratios successfully classified 95.54 percent of the samples as bankrupt and non-bankrupt. A similar study conducted by Elloumi and Gueyie (2001) also examined the association between corporate governance characteristics and financial distress by controlling financial measures indicating liquidity and leverage. The study concluded that board composition explained financial distress beyond the financial measures. Studies by Olsen and Tamm (2017) and Daily (1995) assessed the role of corporate governance measures in a successful reorganisation after a post-bankruptcy trial. Olsen and Tamm (2017) pointed out that during a bankruptcy process, some firms 
significantly change their governance characteristics, such as separation of CEO and chairperson positions, altering the board size, bringing in greater board independence and so on. However, despite these changes, the likelihood that the firm will emerge from bankruptcy does not improve. In contrast, according to Daily (1995), boards with dominant outside directors successfully reorganise after a bankruptcy trial.

Furthermore, the ownership structure is another significant non-financial criterion used in the literature when predicting financial distress. Udin et al. (2016) explored ownership structure proxies on the likelihood of a firm's financial distress. The association of institutional ownership, insider ownership, foreign ownership and government ownership with the likelihood of financial distress was tested along with financial parameters. The study concluded that while foreign shareholding has a significant negative association, insider ownership has a significant positive association with the probability of financial distress. Institutional ownership and government ownership have an insignificant association with the likelihood of financial distress. Manzaneque et al. (2016) examined the role of institutional shareholders as owners and directors in the occurrence of business failure. For this, the institutional shareholders were split into pressure-resistant and pressure-sensitive institution shareholders. Pressure-resistant institutional shareholders include investment funds, pension funds, venture capitalists and holding companies, whereas pressure-sensitive institutional shareholders consist of financial institutions. According to the study, directors appointed by pressure-resistant institutional shareholders negatively impact the likelihood of business failure, and directors appointed by pressure-sensitive institutional shareholders have no impact on the likelihood of business failure. A recent study by Liang et al. (2016) also investigated the role of non-financial variables in predicting bankruptcy in Taiwan. Seven and five categories of financial and non-financial measures were used, respectively. The financial ratios consisted of solvency, profitability, cash flow, capital structure, turnover, growth and other ratios. Board structure, ownership structure, cash flow rights, retention of key personnel and others constituted the non-financial variables. The study concluded that the model with both financial and non-financial ratios performed better when predicting bankruptcy.

While research in bankruptcy has been extensive, especially relating to developing new models or validating existing models, very limited studies in the past have investigated the influence of non-financial variables in the process of developing corporate financial distress prediction models. Further, no studies have considered the role of board independence and promoter ownership in corporate distress prediction models in India. Furthermore, the choice of samples based on bankruptcy filing under the new insolvency and bankruptcy law IBC is new. This study makes a valuable addition to the available literature on corporate financial distress prediction.

\section{Materials and Methods}

\subsection{Population}

Publicly listed industrial corporations constituted the population for the study. The population consisted of financially distressed and financially sound industrial corporations. Bankruptcy filing with the IBC was taken as a reference when identifying financially distressed companies. Companies that had defaulted credit and filed for bankruptcy under the IBC 2016 since its inception up to 31 March 2019 constituted the financially distressed companies. A total of 1756 companies comprising both public and private limited companies filed for bankruptcy during this period. About 602 companies out of the 1756 companies were public limited corporations, and 484 amongst these companies were classified as industrial according to the National Industrial Classification (NIC) 2008, published by the Central Statistical Organisation (CSO), the Ministry of Statistics and Programme Implementation, Government of India. Only 163 of the 484 companies were publicly listed either with the National Stock Exchange (NSE) or the Bombay Stock Exchange (BSE). These 163 companies formed the financially distressed companies in the population. Publicly listed industrial corporations that had not filed for bankruptcy under the IBC constituted 
the financially sound companies. Of the 163 publicly traded industrial companies in the population, the required financial data was completely available only for 82 companies. Table 1 presents the stepwise details in arriving at the 82 financially distressed companies and Table 2 displays the industrial classification of the 82 companies.

Table 1. The sample selection for the study.

\begin{tabular}{lc} 
Total number of firms filing for bankruptcy under the IBC & 1756 \\
Less: Private limited companies & 1154 \\
Public limited companies & 602 \\
Less: Public companies not of an industrial nature & 118 \\
Industrial corporations & 484 \\
Less: Unlisted industrial corporations & 321 \\
Publicly listed industrial corporations & 163 \\
Less: Non-availability of data & 81 \\
Publicly listed industrial corporations with required data availability & 82 \\
\hline
\end{tabular}

Source: Compiled by the authors.

Table 2. The industrial classification of defaulting companies in the sample.

\begin{tabular}{cc}
\hline Industry & Number \\
\hline Manufacturing & 69 \\
Construction & 12 \\
Electricity, gas, steam and air conditioning & 1 \\
\hline Total & 82 \\
\hline
\end{tabular}

\subsection{Sampling Design}

The sampling technique used for the study was a paired sampling design. For each of the 82 financially distressed companies, an equal number of matching financially sound companies was selected. Three criteria were used when choosing the matching financially sound companies:

(a) The company should belong to the same industry as the distressed company;

(b) The firm size of the two companies should be similar;

(c) The company should not have filed for bankruptcy.

An independent sample t-test was conducted to compare the mean asset size of the two groups of companies. Table 3 presents the results of the independent sample t-test. At the 5 percent level of significance, there was no statistically significant difference in the asset size of the two groups of companies, thus confirming a matched pair sampling design.

Table 3. Results of the independent sample t-test.

\begin{tabular}{ccccccc}
\hline Group & Obs & Mean & Std Err & Std Dev & \multicolumn{2}{c}{ 95\% Conf. Interval } \\
\hline 0 & 82 & 7032.26 & 2626.53 & 23784.22 & 1806.294 & 12258.23 \\
1 & 82 & 4416.96 & 1107.32 & 10027.2 & 2213.738 & 6620.173 \\
& & & & & $\mathrm{t}=$ & 0.9175 \\
& & & & & $\operatorname{df}=$ & 162 \\
& & & & & & \\
& & & & & & \\
\hline
\end{tabular}

Source: Computed by the authors.

\subsection{Sample}

The total sample size was 164 companies, which consisted of an equal number of financially distressed and financially sound companies. The sample was further classified into training and testing samples. The training sample was used to develop the model, whereas the testing sample was used to validate the developed model. A total of 120 companies comprising 60 distressed and 60 sound companies were used as the training 
sample to formulate the models, and 44 companies consisting of 22 distressed and 22 sound companies were used as a testing sample to validate the developed models.

\subsection{Variables}

Two criteria were used when choosing the predictor variables. They were as follows:

- There should be representation from the broad categories of financial ratios, i.e., profitability, liquidity, efficiency, leverage and cash flow. In addition, two non-financial variables were also included to investigate the role of non-financial measures in corporate distress predictions.

- The ratios selected under each broad category should have made a significant contribution to a distress prediction model developed in the past.

Table 4 presents the list of predictor variables.

Table 4. List of predictor variables.

\begin{tabular}{cc}
\hline Category & Ratio \\
\hline Profitability & Return on assets (ROA) \\
& Operating profit ratio (OPR) \\
Liquidity & Current ratio (CR) \\
& Quick ratio (QR) \\
Leverage & Debt to total assets ratio (DTAR) \\
Efficiency & Interest coverage ratio (ICR) \\
& Total asset turnover ratio (TATR) \\
Cashflow & Sales to working capital ratio (SWCR) \\
& Cash flow to sales ratio (CSR) \\
Non-financial & Cash flow to total assets ratio (CTAR) \\
& Proportion of independent directors (PID) \\
& Proportion of promoters' share (PPS) \\
\hline
\end{tabular}

\subsection{Data Collection}

Secondary data formed the basis for the study. The financial and non-financial ratios for both the defaulting and non-defaulting companies were collected for five years immediately preceding the filing of bankruptcy by the defaulting companies. The data of the independent variables were collected from the Ace Analyzer corporate database. Data for every year ending 31 March was considered for the study.

\subsection{Statistical Tool for Analysis}

The statistical software package Stata was used for the statistical analysis of the panel data. Binary logistic regression analysis was the statistical tool employed to distinguish a defaulting company from a non-defaulting company. In a binary logistic regression where the dependent variable assumes the value 1 or 0 , logistic regression models the probability of $Y=1$ as a function of predictor variables. The standard logistic function is given below:

$$
\log \frac{P(Y)}{1-P(Y)}=\beta_{0}+\beta_{1} X_{1}+\beta_{2} X_{2} \ldots \ldots+\beta_{n} X_{n}
$$

Taking the exponential on both sides and then solving for $\mathrm{P}$ gives:

$$
P_{Y}=1 /\left[1+e^{-z}\right]
$$

where:

$\mathrm{P}_{\mathrm{Y}}$ : probability of default;

e: the base of the natural logarithm, e = 2.71828;

z: $\beta_{0}+\beta_{1} X_{i 1}+\ldots \ldots+\beta_{n} X_{i n}$;

$\beta_{1}-\beta_{n}$ : coefficients of predictor variables;

$X_{1}-X_{n}$ : predictor variables. 


\section{Results}

The mean and standard deviation of each variable for the distressed and sound companies for five years are reported in Table 5. Except for the DTAR and CSR, the mean values of all the variables were lower amongst the distressed companies. In fact, the mean values of the ROA, OPR and ICR were negative for the distressed group. The standard deviations of the profitability ratios, cash flow ratios and non-financial ratios were higher among the financially distressed group, whereas the standard deviation of the liquidity ratios, leverage ratios and efficiency ratios were higher amongst the financially sound group of companies.

The collected data were checked for the presence of multicollinearity. Multicollinearity causes confusion regarding the relative importance of different independent variables in the model (Wang and Lain 2003). Correlation analysis was undertaken to detect multicollinearity. Table 6 presents the results of the correlation analysis. The table reveals a very high correlation of 0.97 between the $\mathrm{CR}$ and $\mathrm{QR}$ and 0.92 between the OPR and CSR. Thus, the $\mathrm{QR}$ and CSR were eliminated from further analysis.

Table 5. Summary of the collected data.

\begin{tabular}{cccccc}
\hline & \multicolumn{2}{c}{ Financially Distressed Companies } & \multicolumn{2}{c}{ Financially Sound Companies } \\
\hline Variable & Obs & Mean & Std. Dev. & Mean & Std. Dev. \\
\hline ROA & 410 & 4.2776 & 5.6774 & -10.5700 & 19.5811 \\
OPR & 410 & 0.1254 & 0.1521 & -9.7395 & 92.3223 \\
CR & 410 & 1.8431 & 2.0556 & 0.8591 & 0.5574 \\
QR & 410 & 1.3047 & 1.7860 & 0.5485 & 0.3886 \\
DTAR & 410 & 0.8354 & 5.1490 & 0.7268 & 0.6748 \\
ICR & 410 & 30.5939 & 275.4959 & -9.6284 & 65.3209 \\
TATR & 410 & 1.1353 & 0.8490 & 0.6906 & 0.7036 \\
SWCR & 410 & 15.6007 & 106.0997 & 1.7364 & 26.8731 \\
CFSR & 410 & 0.1042 & 0.2794 & 18.6663 & 355.4578 \\
CTAR & 410 & 0.0777 & 0.1022 & 0.0267 & 0.1101 \\
PID & 410 & 0.5078 & 0.0908 & 0.5051 & 0.1610 \\
PPS & 410 & 0.5933 & 0.1726 & 0.4950 & 0.1821 \\
\hline
\end{tabular}

Source: Compiled by authors. Note: Total number of observations was 410 for each group of companies.

Table 6. The correlations between predictor variables.

\begin{tabular}{|c|c|c|c|c|c|c|c|c|c|c|c|c|}
\hline Variables & ROA & OPR & CR & QR & DTAR & ICR & TATR & SWCR & CSR & CTAR & PID & PPS \\
\hline ROA & 1.00 & & & & & & & & & & & \\
\hline OPR & 0.29 & 1.00 & & & & & & & & & & \\
\hline $\mathrm{CR}$ & 0.22 & 0.05 & 1.00 & & & & & & & & & \\
\hline $\mathrm{QR}$ & 0.18 & 0.04 & 0.97 & 1.00 & & & & & & & & \\
\hline DTAR & -0.07 & 0.06 & 0.06 & -0.05 & 1.00 & & & & & & & \\
\hline ICR & 0.08 & 0.01 & 0.07 & 0.08 & 0.01 & 1.00 & & & & & & \\
\hline TATR & 0.29 & 0.07 & 0.07 & -0.11 & 0.04 & -0.03 & 1.00 & & & & & \\
\hline SWCR & 0.04 & 0.01 & 0.04 & 0.03 & 0.01 & -0.01 & 0.20 & 1.00 & & & & \\
\hline NOCSR & -0.19 & 0.92 & 0.04 & -0.03 & 0.05 & 0.00 & -0.05 & -0.01 & 1.00 & & & \\
\hline NOCTAR & -0.01 & 0.33 & 0.04 & -0.05 & 0.06 & 0.04 & 0.08 & 0.01 & 0.28 & 1.00 & & \\
\hline PID & 0.07 & 0.07 & 0.01 & -0.02 & 0.03 & -0.06 & 0.08 & 0.01 & 0.06 & 0.05 & 1.00 & \\
\hline PPS & 0.20 & 0.02 & 0.23 & 0.21 & 0.04 & 0.09 & 0.04 & 0.05 & 0.01 & 0.08 & 0.04 & 1.00 \\
\hline
\end{tabular}

Binary logistic regression was employed for the data analysis. Two logistic regression models, M1 and M2, were developed for predicting corporate financial distress. M1 consisted of both financial and non-financial variables as predictors. On the other hand, M2 only had financial ratios as predictors. The financial distress prediction models were developed based on the random effects approach. The results of logistic regression may be reported as the odds ratios or coefficients. The present study used coefficients to understand 
the type of association between the predictor variables and the probability of financial distress. Table 7 presents the logistic regression results of the two models. For M1, the predictor variables consisted of the ROA, OPR, CR, DTAR, ICR, TATR, SWCR, CTAR, PID and PPS. The estimated coefficients of the ROA, CR, ICR, SWCR, CTAR and PPS were negative, indicating an inverse relationship between the ratios and the probability of distress; in contrast, the OPR, DTAR, TATR and PID had positive coefficients, indicating their direct relationship with the probability of financial distress. However, at a 5 percent level of significance, the associations of only three variables, namely, ROA, CR and DTAR, were statistically significant with the probability of default. The table also reports the Wald chi-square test statistic and the accompanying P-value. The prob > chi2 was 0.000 . As the prob > chi2 was less than 0.05 , the overall model was statistically significant.

Table 7. The results of the logistic regression analysis.

\begin{tabular}{|c|c|c|c|c|}
\hline & \multicolumn{2}{|c|}{ Model 1} & \multicolumn{2}{|c|}{ Model 2} \\
\hline & Coefficient $(\beta)$ & $p$-Value (Sig.) & Coefficient $(\beta)$ & $p$-Value (Sig.) \\
\hline $\mathrm{ROA}$ & -0.5814026 & $0.002 *$ & -0.1243865 & 0.357 \\
\hline OPR & 0.0161626 & 0.950 & -9.252991 & 0.205 \\
\hline CR & -7.160657 & 0.000 * & -2.33185 & 0.001 * \\
\hline DTAR & 5.298384 & 0.014 * & 2.085215 & $0.046^{*}$ \\
\hline ICR & -0.0257942 & 0.862 & -0.007206 & 0.858 \\
\hline TATR & 0.1875257 & 0.950 & -1.717829 & 0.114 \\
\hline SWCR & -0.007434 & 0.582 & -0.0048497 & 0.604 \\
\hline CTAR & -23.73184 & 0.057 & -4.71889 & 0.444 \\
\hline PID & 14.41629 & 0.111 & & \\
\hline PPS & -5.327009 & 0.204 & & \\
\hline Constant & -2.820699 & 0.614 & -0.1267785 & \\
\hline Wald chi2 & \multicolumn{2}{|c|}{94.24} & \multicolumn{2}{|c|}{31.8} \\
\hline Prob > chi & \multicolumn{2}{|c|}{0.00} & \multicolumn{2}{|c|}{0.00} \\
\hline
\end{tabular}

* Statistically significant at 5 percent level of significance.

The predictor variables for M2 were ROA, OPR, CR, DTAR, ICR, TATR, SWCR and CTAR. Table 7 reports the coefficients of ROA, OPR, CR, ICR, TATR, SWCR and CTAR as negative, indicating an inverse relationship with the probability of financial distress. On the other hand, the coefficients of DTAR were positive, demonstrating a direct relationship with the event of distress. However, at a 5 percent level of significance, only the associations of CR and DTAR were statistically significant with the financial status. The prob > chi2 was 0.00 for the Wald test, indicating the statistical significance of the overall model.

The diagnostic abilities of the models were assessed with the aid of the ROC, AUC, sensitivity, specificity, type I errors, type II errors and total annual prediction accuracy. The ROC and AUC for the two models are presented in graph 1. The area under the curve (AUC), i.e., area under the receiver operating characteristic (ROC) curve, maps the sensitivity against 1-specificity. Sensitivity is the percentage of correctly predicted financially distressed companies by the model and specificity is the percentage of correctly predicted financially sound companies by the model. The sensitivity and specificity help to estimate the type I and type II errors. A type I error is the percentage of distressed companies incorrectly predicted as sound, and a type II error is the percentage of sound companies incorrectly predicted as distressed companies. A type I error is computed as (1-sensitivity) and (1-specificity) is the type II error.

For the formulated models, the ROC and AUC are displayed in Figure 1. The ROC is generated using each possible outcome of the diagnostic test as a classification cut point and corresponding sensitivity and (1-specificity). The area under the ROC curve for M1 was 0.8758 , whereas, for M2, the area was 0.8594 . The AUC indicates the overall classification accuracy of the model. An AUC over $80 \%$ is very good. Both models indicate a very good ability to predict financial distress. However, M1 with both financial and non-financial 
measures as predictors had a higher AUC, thus indicating the greater predictive ability of the model.

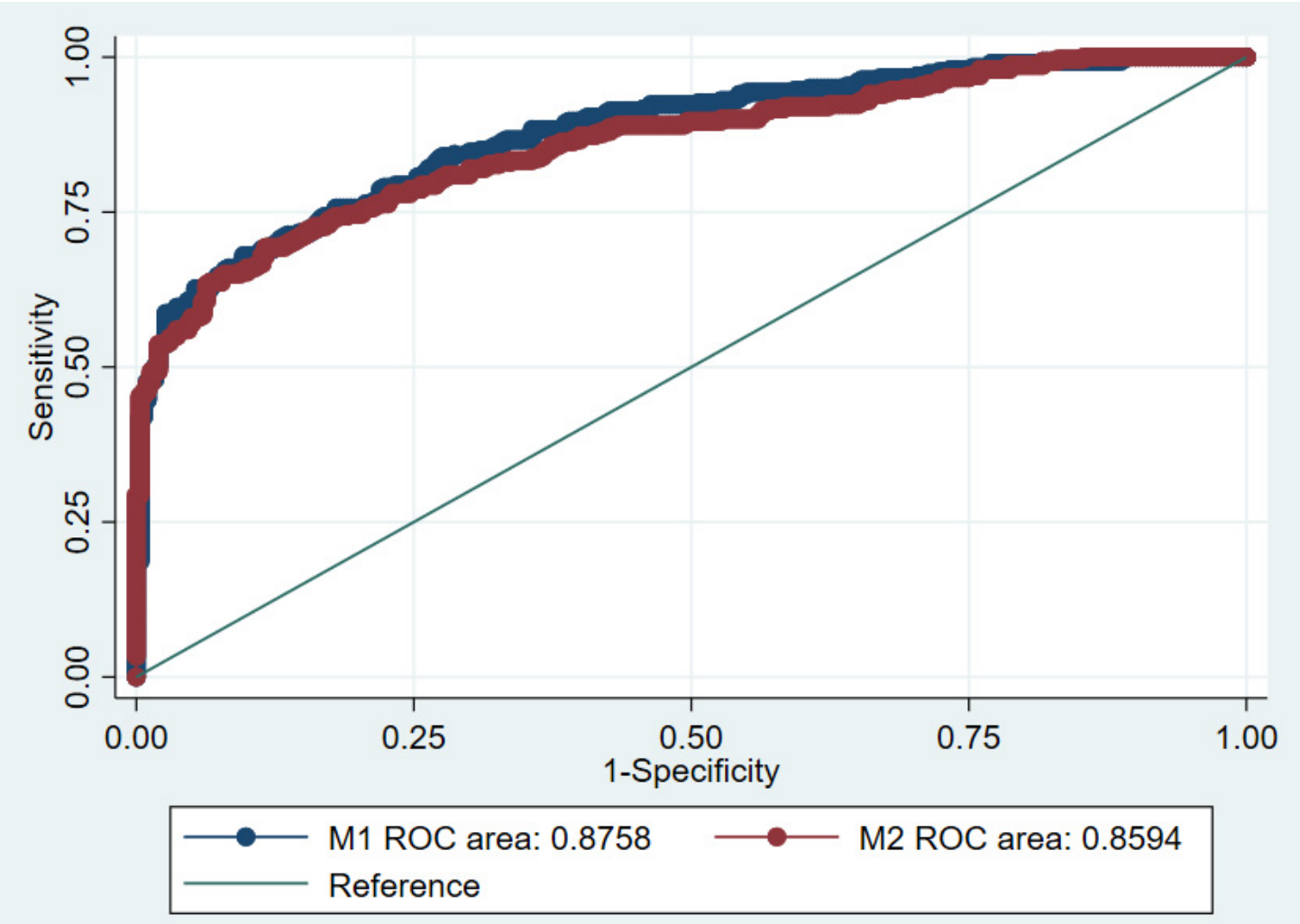

Figure 1. This figure compares the ROCs of the two models.

A cut-off point was determined for each of the models to classify the companies as financially distressed or financially sound. The estimated z-value for each company was compared to the cut-off point to classify the companies into two groups. The present study employed the Liu method to estimate the cut-off point. The Liu (2012) method estimates the cut-off point by maximising the product of sensitivity and specificity. The estimated cut-off points, along with the sensitivity, specificity and area under the ROC curve at the cut-off point, are presented in Table 8.

Table 8. The empirical cut-off point estimations.

\begin{tabular}{ccc}
\hline Method & Liu & Liu \\
\hline Reference variable & Status $(0=$ neg, $1=$ pos $)$ & Status $(0=$ neg, $1=$ pos $)$ \\
Classification variable & M1 & M2 \\
Empirical optimal cut-off point & -4.6314509 & -3.7304994 \\
Sensitivity at cut-off point & 0.76 & 0.69 \\
Specificity at cut-off point & 0.82 & 0.88 \\
Area under ROC at cut-off point & 0.79 & 0.79 \\
\hline
\end{tabular}

According to the Liu method, as displayed in Table 8, the optimal cut-off point for M1 was -4.6314509 , and for M2, it was -3.7304994 . The overall sensitivities at the cut-off point were 0.76 and 0.69 and specificities were 0.82 and 0.88 for M1 and M2, respectively. The areas under the ROC curves at the cut-off points for both models were 0.79 , which indicates the total classification accuracy of the two models at their respective cut-off points. The higher sensitivity of M1 indicates the ability of the model to identify financially distressed companies more efficiently. 
Table 9 presents the annual prediction accuracy of the two models at the estimated cut-off point. An overall accuracy of about 79 percent was displayed by both models. The annual accuracy increased as the year of the bankruptcy filing approached. The overall type I errors were approximately 24 percent for M1 and 31 percent for M2. The type II errors were approximately 18 percent and 12 percent for M1 and M2, respectively. During the five years investigated, the accuracy ranged between 90 and 67 percent for model 1 and between 90 and 64 percent for model 2.

Table 9. The annual classification accuracy of the training sample.

\begin{tabular}{cccccccc}
\hline & & \multicolumn{3}{c}{ Model 1 } & \multicolumn{3}{c}{ Model 2 } \\
\hline \multirow{2}{*}{ Year } & $\begin{array}{c}\text { Total } \\
\text { Cases }\end{array}$ & $\begin{array}{c}\text { Total } \\
\text { Accuracy }\end{array}$ & $\begin{array}{c}\text { Type I } \\
\text { Error }\end{array}$ & $\begin{array}{c}\text { Type II } \\
\text { Error }\end{array}$ & $\begin{array}{c}\text { Total } \\
\text { Accuracy }\end{array}$ & $\begin{array}{c}\text { Type I } \\
\text { Error }\end{array}$ & $\begin{array}{c}\text { Type II } \\
\text { Error }\end{array}$ \\
\hline 1 & 120 & 108 & 4 & 8 & 108 & 6 & 6 \\
2 & 120 & 100 & 6 & 14 & 104 & 7 & 9 \\
3 & 120 & 98 & 12 & 10 & 98 & 16 & 6 \\
4 & 120 & 87 & 23 & 10 & 86 & 27 & 7 \\
5 & 120 & 80 & 28 & 12 & 77 & 36 & 7 \\
\hline & 600 & 473 & 73 & 54 & 473 & 92 & 35 \\
\hline
\end{tabular}

As already discussed, the total sample was classified as a training and testing sample. For validation, the prediction accuracy of the testing sample was assessed. Table 10 presents the annual prediction accuracy of the testing sample. The overall accuracy of M1 was greater than M2. During the five years, the total accuracy ranged between 80 and 60 percent in the case of M1 and between 77 and 57 percent in the case of M2. A comparison of the type I and type II errors of the two models revealed a lower proportion of type I errors in M1 and a lower proportion of type II errors in M2.

Table 10. The annual classification accuracy of the testing sample.

\begin{tabular}{cccccccc}
\hline & & \multicolumn{3}{c}{ Model 1 } & \multicolumn{3}{c}{ Model 2 } \\
\hline \multirow{2}{*}{ Year } & $\begin{array}{c}\text { Total } \\
\text { Cases }\end{array}$ & $\begin{array}{c}\text { Total } \\
\text { Accuracy }\end{array}$ & $\begin{array}{c}\text { Type I } \\
\text { Error }\end{array}$ & $\begin{array}{c}\text { Type II } \\
\text { Error }\end{array}$ & $\begin{array}{c}\text { Total } \\
\text { Accuracy }\end{array}$ & $\begin{array}{c}\text { Type I } \\
\text { Error }\end{array}$ & $\begin{array}{c}\text { Type II } \\
\text { Error }\end{array}$ \\
\hline 1 & 44 & 34 & 1 & 9 & 33 & 2 & 9 \\
2 & 44 & 35 & 1 & 8 & 34 & 3 & 7 \\
3 & 44 & 29 & 6 & 9 & 31 & 5 & 8 \\
4 & 44 & 26 & 8 & 10 & 26 & 10 & 8 \\
5 & 44 & 28 & 8 & 8 & 25 & 12 & 7 \\
\hline & 220 & 152 & 24 & 44 & 149 & 32 & 39 \\
\hline
\end{tabular}

\section{Discussion}

According to the study results, both models were statistically significant and a good fit, as indicated by the Wald test. Although the AUC at the estimated cut-off point for both the models was equal at 0.79, M1 outperformed M2 in three aspects. First, the overall AUC of 0.8758 for M1 was higher than 0.8594 for M2. Second, at the estimated cut-off point, the sensitivity associated with model 1 was 0.76 , resulting in a proportion of type I errors of 0.24 , whereas the sensitivity for model 2 was 0.69 and the resulting proportion of type I errors was 0.31 . As discussed, it is generally agreed upon that type I errors are more costly than type II errors (Gissel et al. 2007). Therefore, the model with the lower proportion of type I errors is desired. Third, in most of the years under study, the annual accuracy of M1 was either greater than or equal to M2 for both the training and testing samples. Thus, the model with both financial and non-financial measures is recommended for corporate financial distress prediction in the Indian industrial sector.

From this study, it can be concluded that the inclusion of non-financial measures improved the predictive efficacy of the corporate financial distress prediction model. This 
result is in confirmation with the study conducted by Liang et al. (2016) in Taiwan, where the model formulated by combining both financial and corporate governance ratios had a better predictive efficacy. The study result is consistent with Elloumi and Gueyie (2001), who rightly pointed out that board composition explained financial distress beyond the financial measures. However, unlike Udin et al. (2016), the study failed to establish a statistically significant association between promoter ownership and the risk of financial distress.

In the recommended model $\mathrm{M} 1$, three financial ratios-the return on assets (ROA), current ratio (CR) and debt to total assets ratio (DTAR) — had statistically significant associations with the probability of financial distress. Both ROA and CR were inversely associated with the event of financial distress, as identified by Singh and Mishra (2016) and Pervan et al. (2011), respectively. Further, as discussed by Shetty et al. (2012), the debt to total assets ratio (DTAR) was positively associated with the probability of distress. However, in contrast to the study by Rashid and Abbas (2011), the total assets turnover ratio (TATR) did not exhibit a statistically significant negative association, and unlike the findings by Obradovic et al. (2018), the sales to working capital ratio (SWCR) did not have a statistically significant positive association with the event of distress. Further, as identified by Bandyopadhyay (2006), Datta (2013) and Waqas and Md-Rus (2018), the operating profits ratio (OPR), interest coverage ratio (ICR) and cash flow to total assets ratio (CTAR) were negatively associated with the event of corporate financial distress, but the association was not statistically significant in the present study.

\section{Conclusions}

Literature on corporate financial distress primarily focussed on recommending new models or validating existing models in a new period characterised by different economic conditions. Further, the existing models are often developed with financial variables and sometimes a combination of financial and non-financial variables. However, recommending a model after considering the role of non-financial variables has received limited attention. The present study made a unique attempt by first developing two models with and without non-financial measures and then compared the performance of the two models to determine the role of non-financial measures in corporate financial distress prediction. The results of the study contribute to the literature by demonstrating the significance of nonfinancial measures, such as board independence and ownership structure, in improving the predictive efficacy of the corporate distress prediction model in the Indian industrial sector.

The recommended model is useful to the stakeholders in the Indian industrial sector, as it provides an early warning of financial distress experienced by businesses. The suggested model can be a wake-up call to the management to plan a turnaround strategy, direct investors in their investment decision, assist creditors with credit risk analysis and assist regulatory bodies with safeguarding the interest of the investors.

The study is not devoid of limitations. The study primarily focused on recommending a model with higher sensitivity and lower type I error. In this process, specificity and type II errors were ignored. The relatively low specificity of the recommended model is a limitation. In the future, researchers may attempt to develop a distress prediction model with increased specificity. In addition, researchers and practitioners can use the research gap presented in this study for further analysis of the role of non-financial variables in corporate distress prediction models. There is also a huge scope for research in exploring industry-specific key indicators that can guide the investors and lenders in learning about the financial status of a company with ease.

Author Contributions: Conceptualization, S.H.S. and T.N.V.; methodology, data, original draft preparation, S.H.S.; review, editing and supervision, T.N.V. All authors have read and agreed to the published version of the manuscript.

Funding: This research received no external funding.

Institutional Review Board Statement: Not applicable. 
Informed Consent Statement: Not applicable.

Data Availability Statement: The data presented in this study are available on request from the corresponding author.

Conflicts of Interest: The author declares no conflict of interest.

\section{References}

Altman, Edward I. 1968. Financial Ratios, Discriminant Analysis and the prediction of corporate bankruptcy. The Journal of Finance 23: 589-609. [CrossRef]

Ayotte, Kenneth, and David A. Skeel, Jr. 2013. Bankruptcy Law as a Liquidity Provider. The University of Chicago Law Review 80: 1557-624. Available online: https:/ / www.jstor.org/stable/23594947 (accessed on 2 December 2020).

Bandyopadhyay, Arindam. 2006. Predicting probability of default of Indian corporate bonds: Logistic and Z-score model approaches. The Journal of Risk Finance 7: 255-72. [CrossRef]

Beaver, W. H. 1966. Financial Ratios As Predictors of Failure. Journal of Accounting Research 4: 71-111. [CrossRef]

Daily, Catherine M. 1995. The relationship between board composition and leadership structure and bankruptcy reorganisation outcomes. Journal of Management 21: 1041-56. [CrossRef]

Daily, Catherine M., and Dan R. Dalton. 1994. Bankruptcy and corporate governance: The impact of board composition and structure. Academy of Management Journal 37: 1603-17. [CrossRef]

Daily, Catherine M., and Dan R. Dalton. 1995. CEO and director turnover in failing firms: An illusion of change? Trategic Management Journal 16: 393-400. [CrossRef]

Datta, Dilip Kumar. 2013. Industrial Sickness in India- An empirical Aanlysis. IIMB Management Review 25: 104-14. [CrossRef]

Deakin, Edward B. 1972. A Discriminant Analysis of Predictors of Business Failure. Journal of Accounting Research 10: 167-79. [CrossRef]

Elloumi, Fathi, and Jean-Pierre Gueyie. 2001. Financial distress and Corporate Governance: An empirical analysis. Corporate Governance 1: 15-23. [CrossRef]

Forbes. 2001. Forbes. Available online: https://www.forbes.com/2001/12/03/1203topnews.html?sh=244f0c282027 (accessed on 12 December 2020).

Fox, Loren. 2004. Enron: The Rise and Fall. Hoboken: John Wiley \& Sons.

Gissel, Jodi L., Don E. Giacomino, and Michael D. Akers. 2007. A review of bankruptcy prediction studies 1930-Present. Journal of Financial Education, 1-42.

John, Nevin. 2019. Businesstoday. Available online: https://www.businesstoday.in/top-story/real-estate-tops-bankruptcy-chartconstruction-metals-and-textiles-follow/story/320088.html (accessed on 12 December 2020).

Jones, Stewart, and David A. Hensher. 2004. Predicting Firm Financial Distress: A Mixed Logit Model. The Accounting Review 79: 1011-38. [CrossRef]

Kim, Hyunjoon, and Zheng Gu. 2020. A Logistic Regression Analysis for Predicting Bankruptcy in the Hospitality Industry. Journal of Hospitality Financial Management 14: 17-34. [CrossRef]

Liang, Deron, Chia-Chi Lu, Chih-Fong Tsai, and Guan-An Shih. 2016. Financial ratios and corporate governance indicators in bankruptcy prediction: A comprehensive study. European Journal of Operations Research 252: 561-72. [CrossRef]

Liu, Xinhua. 2012. Classification accuracy and cut point selection. Statistics in Medicine 31: 2676-86. [CrossRef]

Manzaneque, Montserrat, Elena Merino, and Alba María Priego. 2016. The role of institutional shareholders as owners and directors and the financial distress likelihood: Evidence from a concentrated ownership context. European Management Journal 34: 1-13. [CrossRef]

Ohlson, James A. 1980. Financial Ratios and the Probabilistic Prediction of Bankruptcy. Journal of Accounting Research 18: 109-31. [CrossRef]

Obradovic, Dragana Beslic, Dejan Jaksic, Ivana Beslic Rupic, and Mirko Andric. 2018. Insolvency prediction model of the company: The case of the Republic of Serbia. Economic Research 31: 139-57. [CrossRef]

Olsen, Brett C., and Chris Tamm. 2017. Corporate governance changes around bankruptcy. Managerial Finance 43: 1152-69. [CrossRef]

Pervan, Ivica, Maja Pervan, and Bruno Vukoja. 2011. Prediction of company bankruptcy using statistical techniques- Case of Croatia. Croatian Operational Research Review 2: 158-67.

Rashid, Abdul, and Qaiser Abbas. 2011. Predicting bankruptcy in Pakistan. Theoretical and Applied Economics 18: 103-28.

Sahoo, M., and Anuradha Guru. 2020. Indian Insolvency Law. Vikalpa- The Journal of Decision Makers 45: 69-78. [CrossRef]

Shetty, Udaya, T. P. M. Pakkala, and Thathaiah Mallikarjunappa. 2012. A modified directional distance formulation of DEA to assess bankruptcy: An application to IT/ITES companies in India. Expert Systems with Applications 39: 1988-97. [CrossRef]

Singh, Bhanu Pratap, and Alok Kumar Mishra. 2016. Re-estimaton and comparisons of alternative accounting based bankruptcy prediction models for Indian companies. Financial Innovation 2: 1-28. [CrossRef]

Sridharan, Uma V., Lori Dickes, and W. Royce Caines. 2002. The social impact of business failure: Enron. Americal Journal of Business 17: 11-22. [CrossRef]

Udin, Shahab, Muhammad Arshad Khan, and Attiya Yasmin Javid. 2016. The effects of ownership structure on likelihood of financial distress: An empirical evidence. Corporate Governance 17: 589-612. [CrossRef]

Wang, George C., and Chaman Lain. 2003. Regression Analysis: Modelling and Forecasting. New York: Graceway Publishing Company. 
Waqas, Hamid, and Rohani Md-Rus. 2018. Predicting financial distress: Importance of financial and firm specific market variables for Pakistan's listed firms. Cogent Economics \& Finance 6: 1-35. [CrossRef]

Xu, Kun, Qilan Zhao, and Xinzhong Bao. 2015. Study on early warning of enterprise financial distress- Based on partial least square logistic regression. Acta Oeconomica 65: 3-16. [CrossRef] 